\title{
Pelatihan Penggunaan Software Avogadro untuk Pemodelan Senyawa Hidrokarbon Sederhana kepada Siswa SMA Negeri 5 Maluku Tengah
}

\author{
Mirella Fonda Maahury*, Mario Rowan Sohilait, dan Semuel Simra Pada \\ Jurusan Kimia, Fakultas Matematika dan Ilmu Pengetahuan Alam, Universitas Pattimura, Ambon, Indonesia.
}

\author{
Article history \\ Received: 15-06-2021 \\ Revised: 29-06-2021 \\ Accepted: 13-07-2021 \\ *Corresponding Author: \\ Mirella Fonda Maahury, \\ Jurusan Kimia, Fakultas \\ Matematika dan Ilmu \\ Pengetahuan Alam, \\ Universitas Pattimura, \\ Ambon, Indonesia; \\ Email: \\ mirellafonda31@gmail.com
}

Abstract: Learning Hydrocarbon at the High School requires qualified teaching aids. The limitations of teaching aids make students' knowledge of the spatial structure (3 dimensions) of hydrocarbon compounds not following the content being studied so that they do not achieve the expected competence. In the end, this impacts the difficulty of understanding the same material at a higher level, high school. For this reason, the training on the use of the Avogadro software is expected to provide knowledge to students on how to operate the software, and students can do modeling for simple hydrocarbon compounds. In the end, the students understand how the three-dimensional structure of hydrocarbon compounds looks. We need the help of software that students can use in studying molecular structures, especially hydrocarbon compounds. In this service process, a training method is carried out using demonstrations of the operating steps of the Avogadro software and is followed by all training participants. The results obtained are that the participants (Science class students of SMA Negeri 5 Maluku Tengah) can perform modeling with Avogadro software, drawing 3dimensional structures, optimizing geometry and determining structural parameters of simple hydrocarbon molecules.

Keywords: avogadro; hydrocarbons; modeling; structure

Abtrak: Pembelajaran materi Hidrokarbon pada tingkat Menengah atau SMA membutuhkan alat peraga yang mumpuni. Keterbatasan alat peraga membuat pengetahuan para siswa mengenai struktur ruang (3 dimensi) dari senyawa hidrokarbon tidak sesuai dengan materi yang dipelajari sehingga tidak mencapai kompetensi yang diharapkan. Pada akhirnya hal ini berdampak pada sulitnya memahami materi yang sama pada tingkat yang lebih tinggi yaitu Pendidikan tinggi. Untuk itu, dari Pelatihan penggunaan perangkat lunak Avogadro ini diharapkan memberikan pengetahuan kepada para siswa bagaimana mengoperasikan perangkat lunak tersebut serta para siswa dapat melakukan pemodelan untuk senyawa hidrokarbon sederhana. Pada akhirnya, para siswa jadi memahami bagaimana tampilan struktur tiga dimensi senyawa hidrokarbonUntuk itu, perlu bantuan perangkat lunak yang dapat digunakan oleh para siswa dalam mempelajari struktur molekul, khususnya senyawa hidrokarbon. Pada proses pengabdian ini, dilakukan metode pelatihan dengan cara demonstrasi/peragaan Langkah-langkah pengoperasian perangkat lunak Avogadro dan diikuti oleh seluruh peserta pelatihan. Hasil yang diperoleh adalah para peserta (siswa-siswi SMA Negeri 5 Maluku Tengah) dapat melakukan pemodelan dengan perangkat lunak Avogadro, yaitu menggambar struktur 3 dimensi, melakukan optimasi geometri dan menentukan parameter struktur dari molekul hidrokarbon sederhana.

Kata Kunci: avogadro; hidrokarbon; pemodelan; struktur 


\section{PENDAHULUAN}

Pada era 4.0 sekarang ini, perkembangan perangkat lunak sudah sangat pesat. Perkembangan perangkat lunak ini juga menyentuh bidang pendidikan. Perangkat lunak merupakan salah satu media pembelajaran. Penggunaan media pembelajaran dalam tahap orientasi pembelajaran membantu dan memudahkan proses pembelajaran dan penyampaian materi yang efektif dan efisien (Nursidik \& Suri, 2018). Kemudahan ini menyentuh tingkatan Pendidikan dasar (SD dan SMP), Pendidikan menengah (SMA/SMK), hingga Pendidikan tinggi (Univeristas). Diantara Pendidikan menengah dan Pendidikan tinggi, perangkat lunak dapat dimanfaatkan sebagai jembatan untuk membantu proses pembelajaran yang dihadapi siswa di tingkat menengah dan tingkat selanjutnya. Salah satu Pembelajaran yang dihadapi untuk siswa Ilmu pengetahuan alam adalah Kimia. Di dalam Kimia Ada materi pembelajaran Hidrokarbon.

Pembelajaran materi hidrokarbon di tingkat SMA membutuhkan usaha lebih karena selain berurusan dengan penamaan, sebelum paham akan penamaan struktur molekul hidrokarbon harus dipahami terlebih dahulu. Tim pengabdian sebagai Dosen yang sering mengajar materi mengenai struktur molekul, seringkali menemui banyak mahasiswa yang belum paham benar mengenai struktur dari senyawa-senyawa yang ada. Struktur 3 dimensi masih sulit dipahami karena media pembelajaran yang digunakan kurang membantu. Permasalahan kurangnya pemahaman mengenai struktur 3 dimensi pada molekul hidrokarbon sederhana oleh siswa. Materi mengenai struktur sangatlah penting karena merupakan dasar yang penting dalam memahami materi-materi selanjutnya dan aplikasi ke tingkat semester yang lebih tinggi.

Kesulitan yang ditemui ternyata dapat dijembatani melalui kimia komputasi. Kimia komputasi merupakan cabang dalam ilmu kimia yang menggunakan komputer untuk menyelesaikan beberapa masalah di dalam suatu system kimia. Penggunaan perangkat lunak di dalam kimia komputasi membantu siswa dalam memahami materi mengenai struktur molekul. Hal ini dikarenakan perangkat lunak di dalam kimia komputasi mampu melakukan visualisasi struktur molekul secara tiga dimensi (3D). Salah satu perangkat lunak yang dapat digunakan untuk melakukan visualisasi struktur molekul 3 D adalah Avogadro (Hanwell et al., 2012). Avogadro adalah perangkat lunak open source. Open source artinya gratis dan tidak berbayar. Aplikasi ini memudahkan para penggunanya untuk dapat dengan mudah melakukan visualisasi dan juga perhitungan sederhana di dalam kimia komputasi.

Mitra pengabdian kali ini adalah SMA Negeri 5 Maluku Tengah. Di dalam pemahaman materi hidrokarbon, diperlukan pemahaman yang benar mengenai struktur molekul. Hal ini disebabkan karena ada materi lanjutan hidrokarbon pada tingkat universitas apabila para siswa ingin melanjutkan Pendidikan ke tingkat strata I. Dari uraian tersebut maka perlu dilakukan pengabdian kepada masyarakat dengan memberikan pelatihan kepada siswa mengenai cara penggunaan perangkat lunak Avogadro dalam pemodelan senyawa hidrokarbon sederhana.

\section{METODE}

Program Pengabdian Masyarakat berbasis pelatihan. Sasaran di dalam pengabdian kepada masyarakat ini adalah siswa kelas XI IPA SMA Negeri 5 Maluku Tengah. Mitra untuk pengabdian ini ditetapkan dengan mempertimbangkan efisiensi dan intensitas pelaksanaan program. Jenis permasalahan yang ditangani yaitu kurangnya pemahaman mengenai struktur 3 dimensi pada molekul hidrokarbon sederhana oleh siswa. Permasalahan ini ditemui ketika melakukan pembelajaran pada beberapa mahasiswa asal daerah kabupaten di Maluku yang masih kesulitan untuk memahami struktur molekul. Pada hakekatnya, kegiatan pengabdian kepada masyarakat ini memberikan solusi terhadap 
permasalahan yang dihadapi mitra. Adapun perubahan pasca pengabdian ini yang diharapkan yaitu 1) Adanya pemahaman cara menggunakan perangkat komputer, 2) Adanya pemahaman terhadap penggunaan perangkat lunak Avogadro, 3) Adanya pemahaman struktur tiga dimensi senyawa hidrokarbon sederhana, 4) adanya pemahaman parameter struktur senyawa hidrokarbon.

Pelaksanaan pengabdian dilakukan dengan dua tahapan utama yaitu:

1. Tahap persiapan.

Tahapan persiapan terdiri atas 3 kegiatan, yaitu a) Pembuatan modul untuk nanti digunakan kepada pelatihan kepada siswa-siswa SMA Negeri 5 Maluku Tengah. b) Koordinasi dengan kepala sekolah SMA Negeri 5 Maluku Tengah. c) Melakukan penginstalan perangkat lunak Avogadro pada 25 komputer di laboratorium komputer SMA Negeri 5 Maluku Tengah.

2. Tahap pelatihan

Tahap pelatihan adalah kegiatan pelaksanaan pengabdian yaitu pelatihan kepada siswa-siswi Kelas XI IPA SMA Negeri 5 Maluku Tengah. Kegiatan ini dilakukan sesuai dengan tahapan dan arahan yang sudah dituangkan di dalam modul. Siswa mengikuti pengarahan dari pembicara dan melakukannya pada komputer masing-masing, hingga mampu melakukannya sendiri.

Pengabdian sebelumnya yang dilakukan oleh Yuanita et.al. (2018) menggunakan perangkat lunak Avogadro dan Chemdraw kepada para guru dan siswa IPA MAN 1 Selong. Pengabdian ini berbasis pengenalan perangkat lunak Avogadro dalam memvisualisasi struktur 3 dimensi molekul. Kegiatan ini dikemas dalam bentuk pemberian pelatihan Perangkat Lunak Avogadro Untuk Pemodelan Senyawa Hidrokarbon Sederhana. Pengabdian kali ini berbeda dengan pengabdian sebelumnya karena dilakukan pelatihan Pemodelan senyawa hidrokarbon. Pemodelan yang dimaksud sekaligus melakukan optimasi Struktur untuk mendapatkan struktur stabil serta menentukan Paramater Struktur berupa Panjang ikatan dan sudut ikatan kepada mitra.

\section{HASIL DAN PEMBAHASAN}

Pada abad 21 ini pendidikan dituntut mampu mempersiapkan siswa untuk dapat dan mampu berkembang dengan berbagai kemampuan dan keterampilan. Kemampuan memecahkan masalah merupakan salah satu aspek yang peranannya penting sebagai bekal siswa menghadapi tantangan era sekarang. Namun, hasil dari beberapa penelitian menunjukkan bahwa kemampuan pemecahan masalah siswa masih cukup rendah. Maka pembelajaran dengan menerapkan pendekatan simulasi dan praktekpraktek terkait teknologi keterkinian diharapkan mampu meningkatkan kemampuan pemecahan masalah.

Kegiatan ini adalah bentuk pengabdian kepada masyarakat dan juga merupakan kepedulian dan tanggung jawab kami sebagai dosen dalam rangka ingin meningkatkan pemahaman akan salah satu materi di dalam pembelajaran siswa/siswi SMA yaitu struktur senyawa hidrokarbon. Senyawa hidrokarbon adalah materi yang penting untuk dipahami karena akan bermanfaat sebagai dasar siswa ketika ingin melanjutkan studi ke jenjang yang lebih tinggi.

Kegiatan pengabdian dengan judul: Pelatihan Penggunaan Perangkat Lunak Avogadro Untuk Pemodelan Senyawa Hidrokarbon Sederhana: Penentuan Struktur dan Paramater Struktur Pada Siswa SMA Negeri 5 Maluku Tengah. Tujuan kegiatan pengabdian ini adalah untuk memenuhi kewajiban dosen mengamalkan Tri Dharma perguruan tinggi yang salah satunya adalah melaksanakan pengabdian kepada masyarakat. Selain itu melaksanakan visi dan misi Lembaga Penelitian dan Pengabdian Masyarakat Universitas Pattimura yaitu pemanfaatan Iptek yang dapat memecahkan fenomena dan masalah aktual. Masalah aktual yang dimaksud adalah kurangnya pemahaman mengenai struktur 3 dimensi pada molekul hidrokarbon sederhana oleh siswa-siswi. Permasalahan ini 
ditemui ketika melakukan pembelajaran pada beberapa mahasiswa asal daerah Maluku Tengah yang masih kesulitan untuk memahami struktur molekul. Kegiatan pengabdian kepada masyarakat ini dilaksanakan di SMA Negeri 5 Maluku Tengah.

Pelaksanaan kegiatan pengabdian ini terbagi atas dua kegiatan penting yaitu Melakukan Persiapan ke sekolah dan Pelatihan Penggunaan Perangkat Lunak Avogadro.

\section{Persiapan Perangkat Lunak}

Kegiatan persiapan yang dilakukan adalah mendownload perangkat lunak Avogadro dari situs resminya ke komputer milik sekolah. Komputer milik SMA Negeri 5 Maluku Tengah berjumlah 25 unit Komputer. Situs resmi untuk mendownload perangkat lunak Avogadro yaitu http://avogadro.cc. Kegiatan ini dilakukan oleh ketua pelaksanaan kegiatan pengabdian kepada masyarakat sekaligus sebagai pembicara pada kegiatan pengabdian kepada masyarakat yang dimaksud.
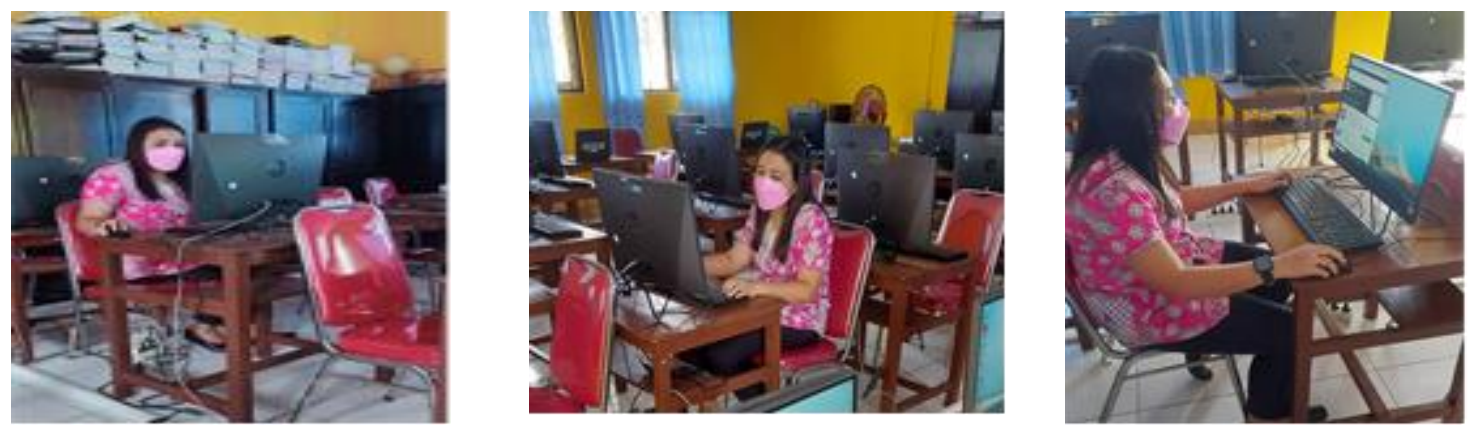

Gambar 1. Dokumentasi Proses Persiapan Perangkat Lunak Avogadro di Laboratorium SMA Negeri 5

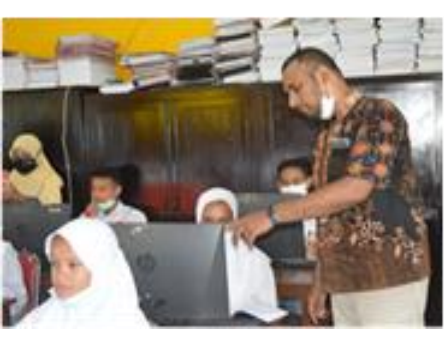
Maluku Tengah.
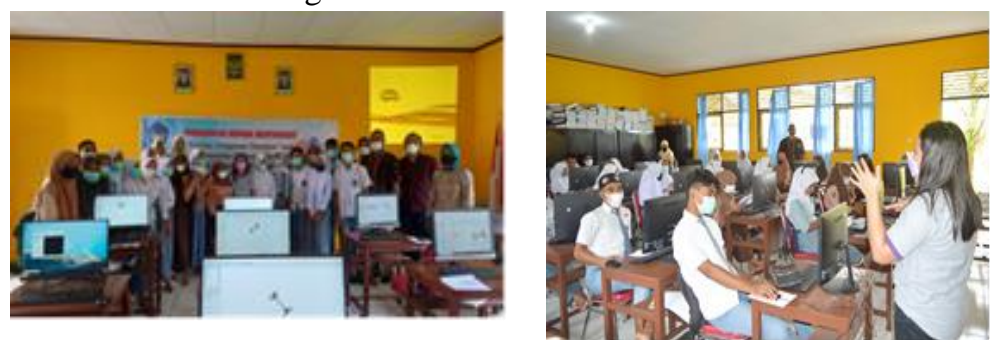

Gambar 2. Aktivitas Kegiatan Pengabdian

\section{Pelatihan Penggunaan Perangkat Lunak Avogadro}

Kegiatan pelatihan diawali dengan membagikan modul untuk penggunaan perangkat lunak Avogadro. Selanjutnya masuk ke materi struktur dua dimensi dan tiga dimensi. Siswa diperkenalkan mengenai perbedaan struktur dua dimensi dan tiga dimensi dari molekul hidrokarbon alkana. Proses penyampaian materi menggunakan metode interaktif dimana siswa-siswi ditanya mengenai pemahaman mereka mengenai materi hidrokarbon. Struktur dua dimensi dan tiga dimensi yang disampaikan adalah metana dan sikloheksana. Kemudian setelah penyetaraan pemahaman mengenai senyawa hidrokarbon dilanjutkan dengan proses pelatihan menggunakan perangkat lunak Avogadro.

Pelatihan penggunaan perangkat lunak Avogadro dimulai dengan demonstrasi atau peragaan tahapan mengoperasikan perangkat lunak Avogadro dan selanjutnya diikuti oleh pada siswa. Apabila para siswa mengalami kesulitan, maka dibantu oleh tim pengabdian yang lain dan juga para guru kimia yang terlibat. Kegiatan dilakukan hingga seluruh siswa mendapatkan hasil sesuai dengan modul yang diberikan. Aktivitas kegiatan pelatihan ditampilkan pada Gambar 2. Para siswa selanjutnya diminta untuk membuat pemodelan senyawa hidrokarbon lain yang telah ditentukan di modul. Ada beberapa molekul yang dimintakan untuk digambar, dioptimasi, dan diukur parameter strukturnya. 
Hasil pekerjaan (menggambar) siswa kemudian dinilai atau dievaluasi. Hasil gambar para siswa cukup memuaskan. Ini menandakan bahwa para siswa telah memahami cara penggunaan aplikasi perangkat lunak ini.

\section{KESIMPULAN DAN SARAN}

Secara keseluruhan kegiatan pengabdian kepada masyarakat di SMA Negeri 5 Maluku Tengah berjalan dengan baik dan para siswa/siswi memahami materi yang diberikan dan mampu menggunakan perangkat lunak Avogadro sesuai dengan demonstrasi yang diberikan. Pengabdian ini direncanakan dengan tema yang sama dengan sasaran kelas siswa yang berbeda yaitu para siswa/siswi kelas X IPA (MIA) SMA Negeri 5 Maluku Tengah. Selain itu, pengabdian akan dilaksanakan ke beberapa sekolah lain di Maluku Tengah dengan materi struktur yang sama atau berbeda sesuai kebutuhan kurikulum pelajaran SMA. Pengabdian kepada masyarakat ini masih menjangkau sedikit kelompok siswa SMA di Maluku Tengah, mungkin lebih diperhatikan untuk dilakukan untuk menjangkau kelompok siswa SMA yang lebih besar.

\section{DAFTAR PUSTAKA}

Hanwell, M., D., Curtis, D. E., Lonie, D. C., Vandermeersch, T., Zurek, E., \& Hutchison, G. R. 2012. Avogadro: An advanced semantic chemical editor, visualization, and analysis platform. Journal of Cheminformatics, 4(17).

Nursidik, H., \& Suri, I. R. A. 2018. Media Pembelajaran Interaktif Berbantu Software Lectora inspire. Desimal: Jurnal Matematika, 1(2), 237. https://doi.org/10.24042/djm.v1i2.2583

Yuanita, E., Ulfa, M., Sumarlan, I., \& Sudarma, I. M. 2018. Aplikasi Chemdraw Dan Avogadro Untuk Meningkatkan Pemahaman Dan Minat Dalam Bidang Kimia. Jurnal Pendidikan dan Pengabdian Masyarakat, 1(2), 6. 